\title{
Summer Employment Policies For Permanent and Temporary Faculty
}

\author{
E. H. Shaban \\ Electrical Engineering Department \\ Southern University B \\ Baton Rouge, LA 70813 \\ eshaban@engr.subr.edu
}

\begin{abstract}
The decision making process of the University Administration with regard to the summer employment assignments for the faculty is discussed. It is shown that the University Administration may concur with recommendations made by a lower hierarchy that may sometime do not comply with the university bylaws, policies, rules, and regulations. A case is discussed where the policies of the department and the rules and regulations of the university may have been overlooked by the hierarchy of the university administration with regard to the summer employment of the faculty members in the electrical engineering department during the summer/2002.
\end{abstract}

\section{Introduction}

All major universities, public and private, have nine months academic year employment contracts for all teaching faculty and the majority of research faculty in undergraduate and graduate programs. Summer schools are approved based on acceptable enrollment of the student's in each course to justify hiring teaching faculty during the summer and the availability of funds. Faculty members who are not engaged in funded research projects within or outside of the university premises seek to apply to teach for the summer school whenever such an opportunity exists. Summer school has been developed in such a way that full semester credit courses can be offered for two weeks, four weeks, and the regular eight weeks, that span the whole summer. The two weeks and the four weeks summer semester full credit courses are mainly offered in the social sciences and the humanity disciplines. Multiple one-hour classes are held in a daily basis to complete the required semester contact and credit hours for each course towards graduation. Such compressed short time span course offerings have benefited both the students and the faculty. The students can obtain semester credit hours towards graduation and the faculty can earn an extra financial income. Both students and faculty can still plan for other activities or a long summer vacation.

Engineering program courses, however, are difficult to teach within two or four weeks session and they are planned for the long summer semester that extends for eight weeks. Classes are taught in a daily basis for a time period of one and half hour in comparison to the regular semester time period. Sometimes, in some departments, there may not be 
enough courses offered with acceptable student's enrollment to allow the available teaching faculty to have full time or part time teaching assignments in the summer. If the number of courses offered are smaller than the number of qualified faculty, a problem may arise. Sometimes some faculty members may be asked to teach courses that they do not normally teach during the regular academic semester or the courses that are offered are outside the area of their expertise.

The chairman of the department is responsible for the assignment of the summer loads among the faculty. Sometimes he (she) follows the approved summer policy in the department and sometimes he (she) uses his (her) own discretion. Unfortunately, a fair and equitable faculty summer employment assignments have not been accomplished in some cases in the electrical engineering department. Some faculty members had complained verbally or in writing by filing grievances that did not materialize in favorable resolutions to the faculty members. Some universities have established policies to regulate the faculty summer appointment in each department. Such policies have not been enforced in a regular basis and unfair summer load assignments for the faculty has taken place. Prejudice, personality conflicts, and favoritism may interfere that lead to faculty discontent and resentment. Some faculty has challenged the enforcement of the summer employment policy in the courts.

This paper addresses a practical experience that has occurred in the electrical engineering department concerning the summer faculty load assignment and the lack of enforcement of the approved summer policy by the chairman and the hierarchy of the University Administration.

\title{
Summer load assignment in the electrical engineering
}

In the summer of 1989, a senior, tenured, full professor, faculty member was denied a summer teaching employment. At that time a summer employment policy existed in the department with a specific written schedule giving the faculty member the highest priority to teach that summer. The faculty member filed a grievance and sought legal counsel. The grievance route through the University Administration did not result in a favorable resolution to the faculty member's satisfaction. The faculty member sued. During the discovery process, it was disclosed that the faculty member gave a graduating senior an unsatisfactory grade in a course that he taught in a regular basis. The department asked the faculty member to reconsider a grade change for the graduating student and the faculty member refused. An administrative decision allowed the student to take an extra test and the student graduated. This incident created an unpleasant environment and personality conflict for the faculty member involved with the department. The lawyer used this case during the trial to support the faculty member's lawsuit. The court agreed with the faculty member claim and awarded him the financial loss he suffered for teaching during the summer of 1989 [1].

In the summer of 1996, a similar case took place in the same department between a faculty member and another chairman. The faculty member did not teach any courses

\author{
Proceedings of the 2003 ASEE Gulf-Southwest Annual Conference \\ The University of Texas Arlington \\ Copyright $(\mathbb{C}) 2003$, American Society for engineering Education
}


during the previous four consecutive summers. He had full time summer internship with the industry. However, the chairman chose to deny the faculty member any full or part time employment in 1996 summer. The chairman awarded himself full time summer employment and he appointed two other faculty members as full time as well. The faculty member complained in writing to the dean with a copy to the Vice Chancellor for Academic Affairs. The dean intervened and sought a part time employment for the faculty member to work in a research project on campus for another department to avoid any confrontations.

In 1997 summer, a new interim chair was appointed. During the summer, he appointed himself as full time, gave one faculty member full time, and a second faculty member two third of full time. He gave a third faculty member one third of full time. This is the same faculty member who was denied fair summer employment in 1996. Prior to the appointment of the current interim chair, there was a personality conflict between the newly appointed interim chair and the third faculty member. When the faculty member asked the interim chair why he gave one of the faculty members two third of full time? The interim chair said because the faculty member had more children. The faculty member filed a grievance and was denied up to the level of the Board of Supervisors.

In 1999 summer, the same interim chair denied the same faculty member a fair and equitable summer employment. The faculty member filed a grievance and was denied up to the level of the Board of Supervisors. The faculty sued and the case is still bending.

In 2001 fall, a recent Ph.D. graduate, an alumnus of the University, with no prior experience in academia, was appointed as an associate professor and an interim chair for the electrical engineering department. Some senior faculty members objected quietly but one faculty member objected publicly and in writing. In the summer of 2002, the new interim chair denied two tenured senior faculty members any summer employment. One of the faculty members is the one that was denied fair summer employment before. The chairman appointed himself full time for the summer/2002. He appointed a faculty member from a technology program to teach two third of full time in the electrical engineering program. In addition he appointed two temporary faculty members for two third and one third of full time during the summer. The two senior and tenured faculty members filed separate grievances for denial of any summer employment in 2002. The faculty member who was denied fair summer employment before, filed his grievance first and was denied up to the level of the Board of Supervisors.

When the second faculty member filed his grievance, it was denied at the level of the chair, the dean, and the Vice Chancellor for Academic Affairs. The Chancellor, however, concurred with the second faculty member in his claim and awarded the faculty member a relief. This was a disparate treatment. The question is why did the Chancellor, the President, and the Board denied the first faculty member a fair and equitable summer employment relief and at the same time the Chancellor concurred with the second faculty member grievance and awarded him a relief? Both faculty members are tenured associate professors in the electrical engineering program. However, the first faculty member is a 
naturalized USA citizen while the second faculty member is a USA born citizen. The first faculty filed a complaint with EEOC. EEOC is investigating the matter.

\section{Bylaws, Rules, and Regulations of Southern University}

Southern University Board of Supervisors has a published Bylaws, Rules, and Regulation that govern the faculty personnel matters [2]. In accordance with the Board of Supervisors Bylaws in Chapter II, Section 2.8.C "Summer Appointment" it states that, "Each department shall work out a plan for summer employment that is fair and equitable, taking into consideration the availability of funds, demand for courses, professional experience and qualifications of departmental faculty members. Such departmental plans shall be subject to the approval of the appropriate dean, the chief academic officer and the chancellor. "While the Bylaws require that each department must have an approved summer plan (policy) for the faculty, sometimes summer policies do not exist, and if they exist they are rarely enforced.

In the fall of 1997 a committee was formed in the electrical engineering department to suggest a summer employment policy. The committee suggested that since the chairman had a nine months contract similar to the faculty, then the chairman must be treated in an identical manner like the rest of the faculty as far as the summer employment is concerned. The chairman did not like that policy. He formed another committee to suggest a summer policy to that suited his taste. They proposed and approved a new summer employment policy [3].

In the 1999 summer employment grievance, the existing 1997summer policy was challenged by the same faculty member who was denied a fair summer employment before. The University directed the department to adopt a new summer employment policy to eliminate the ambiguous language in the1997 policy. A new policy was suggested and approved in January 2000 [4]. Item III in the new policy states the following, "If there are more professors (and the chairperson) than the courses, then we should look for the data of the past five years and the professor who has the minimum part time summer employment get the priority for teaching."

Item III in the 2000 policy, its interpretation, and enforcement was crucial during the summer employment assignments in 2002, adopted by the new interim chair. The interim chair suggested that since the faculty members have a nine (9) months contract, there was no obligation from the University to employ any faculty member, tenured or tenuredtrack, during the summer. Therefore he had latitude to appoint whom he might think was most suitable to teach the summer courses.

In 2002 summer, the electrical engineering (EE) program offered nine (9) courses and the electronic engineering technology (EET) program did not offer any courses at all. There were more courses (nine courses) offered during the summer 2002 than the number of faculty members available for teaching from both EE and EET programs (a total of seven). This fact falls under item III of the summer employment policy 2002. That is there are more courses than professors. There were five (5) faculty members from the 
electrical engineering (EE) program, three were tenured, one was tenure-track (interim chair), and one was a part-time temporary. There were two (2) electronic engineering technology (EET) faculty members, one was tenured and one was temporary.

The new interim chair appointed himself full time, teaching two courses and conducting the department administration. He appointed two faculty members from the EE program. One is a twelve (12) months dean/faculty member and the other a part-time temporary faculty member. They both had two courses or 6 hours that amounted to a two third of full time. He appointed a tenured faculty, and a temporary faculty from the EET program as a two third and one third of full time respectively to teach courses offered in the EE program. He denied two tenured and senior faculty members from the EE program any summer employment in 2002. Since there were a total of seven (7) faculty members in the EE and EET programs combined, each faculty member could have one taught one course with two extra more courses that could have been assigned based on item III of the summer policy 2000.

Furthermore, the Bylaws of Southern University states that the summer policy should take into consideration the professional experience of the departmental faculty. The two senior and tenured faculty members who were denied summer employment in 2002 , taught the courses that were offered in the summer 2002 during the academic year. The two EET faculty members appointed by the interim chair did not teach any of the courses assigned to them in the EE program before.

During the regular academic year, tenure faculty has the right for continuous employment compared to the temporary and the part-time faculty. It is reasonable to assume that the tenured faculty members who are qualified to teach the courses offered during the summer should have preference for employment as well compared to the temporary and the part-time faculty. This fact may be interpreted from the Bylaws of Southern University in Chapter II Section 2.8.C. "Summer Appointment" that states in part, "..taking into consideration ...the professional experience and qualifications of the departmental faculty members". The new interim chair decided that he could appoint a part-time temporary faculty member from the EE program as two third and a temporary faculty member from the EET program as one third and deny the tenured faculty in the EE program any summer employment for the courses that they taught in a regular basis in the EE program.

Such abuse of authority by the interim chair will have a demoralizing effect on the senior and tenured faculty. Such action is neither beneficial to the students nor to the morale of the senior tenured faculty. It is unacceptable that an interim chair appointed as a tenuredtrack associate professor and with no experience in academia should be allowed to take charge of the department administration. Despite the obvious abuse of the interim chair authority, the university concurred with his decision and his interpretation to the bylaws and the summer policy 2000 in the electrical engineering deepartment.

The above strong arguments were made in the grievance filed by the first faculty member, but the university administration denied his grievance including the Board of 
Supervisors. They stated that the Bylaws, rules, and regulation are only guidelines and procedures. Such guidelines and procedures do not give a faculty member a right and they are not a contract that can by enforced under the law. The chairman can consider the faculty for employment but he has the discretion to chose whom to employ during the summer.

Some departments, within Southern University, have recommended, adopted, and implemented a fair and equitable rotational summer employment among the faculty members. A written schedule is distributed a year or two years in advance describing clearly the possible courses that are offered in the summer and the potential faculty members qualified to teach them. This is a successful practical summer employment. The faculty can plan ahead how they would like to spend their summer. This may improve faculty summer employment and avoid the chairman decision to make unreasonable, arbitrary, and prejudiced summer employment decisions. Such plans are highly recommended to other undergraduate engineering institutions.

Research oriented engineering schools faculty members do not seek summer teaching employment. Research faculty has a paid summer employment from funded research contracts. Engineering undergraduate or graduate courses, in research-oriented universities, are rarely offered in the summer. The graduate students are involved in research and the majority of the undergraduate students seek summer employment or coop opportunities to compliment their engineering practical experience. Some engineering schools inform the faculty, when they are hired, that there is no summer employment and the faculty must seek other employments during the summer.

\section{Summary and conclusion}

Undergraduate engineering schools have heavy teaching loads (12 to 15 credit hours) that do not provide time to write proposal, attract funds, and conduct summer paid research. Summer employment in the industry or Government National Labs, are usually competitive depending upon a match between the applicant's interest or experience and the National Labs on going research. The Bylaws of the University has stated that a summer appointment policy shall be made in each department. Unfortunately, some chairmen abuse their authority and try to punish dissident, or opponent faculty members by denying them a fair and equitable summer employment. These actions have led to law suits that were successful in part and denied in part the result of which a complete distraction from the mission of educating future engineers.

\section{References}

1. Guraham Grewel VS Southern University, case \# 346,143 $19^{\text {th }}$ District Court, Baton Rouge, LA 
2. Bylaws and Regulations of the Board of Supervisors of southern University System, www.sus.edu.

3. 1997 electrical engineering summer policy.

4. 2000 electrical engineering summer policy.

\section{Biographical Information}

E. H. Shaban is an associate professor in the electrical engineering department. He attained the BSEE and MSEE in 1968, and 1978 from the University of Khartoum, Sudan, and the Ph.D. from the University of Florida, Gainesville, FL in 1986. He worked as a visiting professor at the University of Puerto-Rico, Mayguez in 1987-88, after which he joined Southern University, Baton Rouge, LA. 